\title{
Unintentional Consequences: Facing the Risks of Being a Youth Activist
}

\author{
Darren E. Lund and Rae Ann Van Beers
}

University of Calgary

Authors' Note

Darren E. Lund, Werklund School of Education, University of Calgary; Rae Ann Van Beers, Werklund School of Education, University of Calgary.

This research was supported by a grant from the Social Sciences and Humanities Research Council (\#410-2011-0664). We would also like to thank Sonia Aujla-Bhullar and Hayley Allery for their helpful assistance with this research project.

Correspondence concerning this article should be addressed to Darren E. Lund, Werklund School of Education, University of Calgary, Calgary, AB. E-mail: dlund@ucalgary.ca

\begin{abstract}
Students involved in social justice activist groups and activities encounter several potentially negative consequences in advocating for issues that are important to them. Through duoethnographic interviews with scholar-activists, former youth activists describe the barriers they experienced as socially engaged young people, including dealing with pushback from their cultural, school, and even activist communities. Without adult allies to help mentor them through these processes, the negative emotions associated with these encounters can lead youth to burn out and leave activism altogether. The findings of this study remind educators that they have an important role to play in providing meaningful activist training, apprenticeship opportunities, and supports for youth who are passionately engaged in progressive social and political action.
\end{abstract}

Keywords: social justice activism; youth; duoethnography; student movements 


\section{Unintentional Consequences: The Risks of Being a Youth Activist}

In adding to the growing body of literature on youth activism for social justice, this study sought to gain the insights of former youth activists directly, seeking their views on the joys and challenges of this work. Through in-depth interviews with a range of young people who had taken leadership roles in their earlier years as secondary students, we tapped into a rich vein of wisdom on the lived reality of pursuing social justice ideals. A recurring theme that emerged in all of the interviews surrounded the significant risks and challenges that young people faced when they undertook activist work in their schools and communities. This article documents some of the key findings along that topic, with implications and suggestions for students, educators, and others who do this important work in our communities.

Many young people have chosen to organize initiatives to foster acceptance in schools and communities across North America, but relatively few studies have addressed the nuances of this work from the perspectives of the youth activists themselves. Through an earlier pilot project, the lead researcher sought to answer this need by developing an interactive, web-based resource for school activists, based on interviews with student and teacher activists (Lund, 2011; Lund \& Grain, 2012). Social justice activism in this study includes educational activities, lessons, school or community displays, political engagement, arranging guest speakers, group activities, awareness events, media campaigns, and other events on issues of race, ethnicity, sexual orientation, and ability, among other diversity issues.

Engaging current and former student activists as active participants in educational research resists a growing backlash toward youth culture in general. Giroux (2003) noted that "youth" as a social category may be positioned to instill fear, a problem to solve, or a danger to adult society. Rather than accepting the societal beliefs that they are not yet fully formed citizens who lack capacity, who are more likely to cause social problems rather than assuage them (Coe et al., 2015), many youth engage in activism which, by definition, involves some form of action. From organizing protests that support basic human rights to advocating for increased social programming to raising awareness about destructive consumer habits, young people have been instrumental in pushing for social change for several years (Conway \& Morrison, 2007; Forenza \& Germak, 2015; Gordon \& Taft, 2011; Taft, 2011). Young people are just beginning to be engaged in meaningful ways in educational research on social justice activism, and their understandings of the complexities of this work remain largely unexamined. This research directly engaged former youth leaders as informants and collaborators in the struggle to make schools and communities more equitable.

\section{Understanding Youth Activism}

Schools typically promote civic engagement programs and activities that are deemed to be representative of what adults have determined future "good citizens" should be and do (Flacks, 2007). As Kennelly (2009a) pointed out, those attributes do not include pushing against current systems but instead encompass activities such as voting, volunteering, and raising funds for what are deemed worthy charitable causes either in the community or globally. When students do try to push agendas that are not supported by their schools or the administration, they are likely to be considered "bad activists" (p. 127). When added to their traditional and limiting gendered expectations as young women, female activists can face additional barriers due to their gender (Gordon, 2008; Harris, 2004; Taft, 2011). 
Youth who engage in activism often do so because they see it as being linked to their personal identity, engaging in activist work simply because it is their "thing." As Taft (2011) noted, "Activist identity requires doing; it has to be performed through the ongoing practice of activism" (p. 182). In spite of their dedication to activism for the sake of significant social causes, the political engagement of young people is often trivialized by adults who may question their motivations and effectiveness at influencing change. For instance, students who walk out of school as a means of protest are often interpreted simply to be "cutting class" (Cabrera et al., 2013 , p. 8). Such adultist views plague the activities of youth activists who must continually counter tokenistic perceptions (Best, 2007; Gordon, 2007). While participating in such work creates alignment for young people in terms of their activist identities, activists of all ages can experience negative effects from such engagement, with burnout being the most noticeable issue faced (Gorski, 2015; 2019; Gorski \& Chen, 2015; Kennelly, 2014).

\section{Research Approach}

We formulated flexible guiding research questions generated from experiences and ongoing research in this field. Seeking a respectful engagement with the everyday social justice work of the participants, we employed a dialogic approach with our participants following duoethnography (Norris et al., 2012). By using an innovative model of participatory research that pays deliberate attention to matters of social justice, we acknowledged power relations along with the our own identities and assumptions. Building on insights from other duoethnographic studies Darren E. Lund has undertaken using this method (see Evans \& Lund, 2013; Nabavi \& Lund, 2012), we sought to understand participants' perspectives through a collaborative interview process.

The guiding research questions for this study were "How do former student leaders conceptualize and articulate their social justice education and activism?" and "How might the frustrations and limitations of activist work as identified by former student leaders in social justice, best inform those wishing to encourage greater youth participation in social justice projects?"

We are both educators with experience in coordinating social justice projects. Rae Ann Van Beers was a research assistant enrolled in doctoral studies full-time during the project. The study itself was planned as a means of community-building among social justice advocates. Rather than downplay our past experiences in the field, we have successfully benefited from our roles as activist "insiders" to obtain more relevant and sound data.

The 12 participants cited in this article were recruited using a range of convenience sampling methods (Creswell, 2007) that drew on the our national networks of community activists, social justice educators, youth groups, and other people involved in this work (Lund \& Van Beers, 2019). For our study, we employed word-of-mouth, telephone, Internet searches, social media sites, media archives, and informal community surveys to identify past social justice projects and their student leaders. During data gathering, we arranged and conducted telephone, face-to-face, and online interviews with a range of participants for this research. Efforts were made to sample a diverse mix of past student leaders from a range of cultural and identity backgrounds. The 12 participants included 10 people who identified as female, and two as male; three females self-identified as people of colour, one of which also identified as queer; and one participant identified as Métis, and one as Indigenous. Each met the criteria of having 
held leadership roles, having taken an active part in planning and implementing social justice activities or projects, and having been involved in the activism directly for at least one full year.

All of the appropriate permissions to conduct this research were sought and obtained from all of the necessary sources in accordance with the ethical standards of the funding agency (see Authors' Note) and our University's research ethics board. Individuals were interviewed during face-to-face or Skype visits in a number of locations following the protocols of duoethnography (Sawyer \& Norris, 2013). Duoethnography is a dialectic form of inquiry through which researchers build upon and extend narrative and autoethnography genres, in which all participants are regarded as co-researchers. Through a collaborative process of meaning-making, life histories are considered as a curriculum, and participants are asked to examine their understandings. Data were gathered from transcribed interviews and field notes, and we undertook initial data coding and analysis, again following steps outlined for duoethnography (Sawyer \& Norris, 2013). As we reviewed the transcribed conversations and notes, we were intentionally honouring "multiple dialogues, surfacing subjugated knowledge, engaging in critical collaboration, [and] finding synergy between data collection and analysis" (Sawyer \& Norris, 2013, p. 40). Attending to the meanings of the participants, we independently identified key themes and interchanges, and then collaborated on our writing, presenting here the insights most relevant to this research focus.

\section{Research Participants}

The individuals who lent their stories to this study came from diverse backgrounds and entered into activism for a variety of reasons. Both Linda and Katie ${ }^{1}$ were involved in their high school social justice group where they were exposed to issues and causes they had never encountered before, but that influenced them to embrace activism during their post-secondary studies as well. Dallas, on the other hand, grew up in a politically active family in which her educator parents encouraged her involvement in social justice work in high school. Leah fought her Catholic high school administration in order to form a GSA for herself and her LGBTQ+ peers. Chantal was also heavily involved in creating and maintaining safe spaces for LGBTQ+ youth, as a queer woman of colour herself, working with community organizations to find space and funding for the events and projects they wanted to engage in. Abigail, a Métis woman, used her social media skills to become an effective youth organizer within the Idle No More movement. She believed that her success in bringing people together resulted in resentment on the part of some adult activists, causing her to redirect her work and energy into helping to start the Indigenous Nationhood Movement.

Simran's involvement in her local Sikh community encouraged her activism, both within that community, and as she moved into post-secondary studies. Her passion for justice and equality resulted in planning events at her university to educate her peers about the Sikh faith. Similarly, Dawn worked to combat racism at her institution and to improve access to supports for herself and other Indigenous students. Parmis' post-secondary activist involvement grew out of her high school experiences as an Iranian youth, where she initiated diversity and multicultural clubs so that she and her classmates could find a place to belong during their lunch breaks. Safe spaces were so important to Amelia and Josh that they co-founded a dedicated space in their high school for students to engage in social justice initiatives. Their prior experiences as youth working in activist circles made them realize the important role that mentors can play in supporting the work of younger activists. Jared was a student who benefitted from their mentorship. 


\section{Findings and Discussion}

In their interviews, participants revealed, by freely describing their successes and growth, that they valued the activist work they engaged in through their schools or as concerned individuals. Despite these positive accounts, their stories shared a common, concerning theme: Every one of these participants encountered barriers and pushback from within their own cultural, school, or activist communities. In some cases that pushback came from the participants' own cultural or geographical communities, while others felt it from school administrators and the general structure of educational systems. Still others explained how they felt bullied or undervalued by older activists they encountered in activist circles. Facing these barriers placed a heavy weight on some of the participants, and their stories show that misconceptions about youth and their abilities are still prevalent in activist circles. By sharing their experiences of dealing with obstacles from their communities, the participants provided insight into the role that educators can play in improving the experiences of youth activists.

\section{Barriers Within Communities}

At times, problems arose simply because of the traditional, problematic norms that were present in the particular locations that these youth grew up in. Exposure to issues like homophobia and racism, when mediated with adult guidance, can provide valuable learning experiences for youth who are interested in walking an activist path. Personal interest in better understanding these issues sometimes required stealth on the part of the youth and their adult allies (Sazama, \& Boston teens, 2013). Linda recalled her high school activist group arranging an LGBTQ+ presentation, an experience that revealed to her as a straight, cisgendered White female both the difficulties of doing social justice work in a potentially hostile environment and the danger that members of this marginalized group experience within her own community. She explained,

We had to be rather quiet with how we promoted it but we had a gay man and a lesbian woman come in and talk about their experience of discrimination ... and I remember we really couldn't talk too much about it; it wasn't that we hid it but [we called it] a diversity presentation 'cause if it was a gay presentation we might have had problems with teachers and parents and stuff. And I remember that being really powerful.

Such an experience helped Linda and her peers in understanding how to engage strategically with these ideas and experiences, and not shy away from activist work even though pushback might occur at both the community and school levels. Her work in organizing these first speakers soon led their school to be the first in its area to form a Gay/Straight Alliance program. The hushed nature of the presentation within the school itself indicates the challenge by many in her community to even speak about either LGBTQ+ issues or homophobia itself. Linda's subsequent description of how the same woman who gave the presentation had a cross burned on her lawn shows how dangerous speaking out against injustice and inequity can be for specific individuals in the very communities they call home. It is vital for educators doing this type of work to show students who may not have already witnessed them the dangers inherent in engaging in social justice initiatives, while at the same time providing a safe space in which all students can learn about and process their new understandings.

Some participants' experiences were much more personal. While some youth have to deal with homophobic attitudes because of their individual gender and/or sexual identities, others have lengthy histories of combatting racism in their day-to-day lives. As a self-identified 
Indigenous person, Dawn spent her life dealing with racism, and was not spared from it as a university student. In her interview she brought up a university newspaper opinion article entitled, "First Nations Don't Deserve Squat," which she and her fellow Indigenous students countered with a two-page editorial. Having to constantly "fight this stuff" can be draining for many youth whose very identities are attacked in mainstream communities and societies.

Simran also spoke of the blatant racism that she encountered in her youth. A proud and active member of the Sikh community, Simran reflected on negative reactions to the Sikh community's attempts to both celebrate and share their faith and culture with others by hosting a parade. Even though Simran and her peers had grown up in the city this incident happened in, they were faced with graffiti on their temple walls depicting Nazi symbols, the word terrorist, and the insulting phrase, "Go back home, you monkeys." She said, "Even if it was just a handful of people, it brought [racism] to the forefront for the youth. Like this still is something that's going to hit us in the face every time we try" to showcase their religion and culture in public.

Unfortunately for Simran and her friends, other attempts to educate the public about their background created tension between them and the elders of their own culture that they were striving to spotlight. In a bid to educate both themselves and their university peers about Sikhism, the youth researched and then performed a play about important historical Sikh women, one of whom was the sister of the first Sikh guru. While their artistic endeavour was wellreceived at the university, Simran said, the youth,

had a lot of negative feedback from our own community about the fact that we portrayed real life. Sikhism doesn't believe that you should ever have anyone who is a religious teacher, you can never portray them in acting or drama or anything like that. So, because we did something like this, it was hit with a lot of controversy.

Pushback from their cultural community was strong enough to prevent Simran and her peers from undertaking this particular educational enterprise again. Simran said she "spoke up against [the negative interpretations of the work] a lot because it was about learning, right?" Rather than deal with the fallout from any possible future renditions of the play, however, the group felt forced to turn to other methods of engaging with the larger university community.

\section{Barriers Within School Communities}

Attempts to engage politically in ways that fall outside traditional norms create problems for youth in schools as well in their communities and cultural groups. Leah pushed the bounds of good citizenship in her school and became a "bad activist" (Kennelly, 2009a, p. 17) by trying to establish a Gay/Straight Alliance in her Catholic high school so that all LGBTQ+ students, including herself, could feel safe and supported. After several rejected requests from administration, Leah was finally able to officially organize the school's GSA but afterwards, the principal took away their right to designate a name for their own group by giving them a boardapproved name that masked their identity as an LGBTQ+ organization. Adult attempts to override youth-initiated movements and ideas can lead to these youth feeling betrayed by the very individuals who are put in place to protect them (Gordon, 2010).

It is not just individual administrators who can leave youth feeling misunderstood and frustrated, however. School structures themselves can impede the development of an activist identity. Josh, an activist educator who worked as a co-facilitator of a student-driven space in a large urban high school, noted that there were few access points for social justice in school. With 
limited ways of being invited into activist circles (Kennelly, 2009b), youth may miss opportunities to find issues they are passionate about and then collaborate with others to make progressive changes in the world around them. The whirlwind pace of schooling further limits youth exposure to activism as teachers are often left scrambling to get through the curriculum in time for final exams. And yet, as Josh pointed out, sometimes students simply need time to work through the high-level concepts that are involved in activist work. He shared that one younger student was struggling to understand a particular talk about feminism and because he knew the person well, he was able to recognize that the student "is not going to get it right now. You have to let him go home and have conversations with other people and read up on this. You can't just harp." The frenetic pace of the school year may limit the curricular connections that could be introduced in other courses, thus diminishing the number of pathways that students can travel towards social justice work (North, 2008).

\section{Barriers in Activist Communities}

Though Parmis, Linda, Katie, Jared, and Amelia told us they appreciated opportunities to get involved in activist work during their high school years, they along with other participants expressed concern about the unforeseen struggles they encountered when they entered the field on their own after graduation. Time spent working with teachers who strived to create safe spaces for students to engage in activism may have provided the youth with a particular understanding of activist movements as encouraging and community-minded spaces. Upon leaving high school, however, youth may find themselves in a different world of activism, one that is not as warm and welcoming. For instance, some young people may experience disrespect at the hands of seasoned activists. Such experiences can drain young, idealistic activists, leaving them jaded and burnt out early on in their activist careers. Dallas's reflection on her own work in the activist world provides an illustration of the struggles that youth can encounter within various movements. In responding to the question of whether she had experienced backlash from the work she had done, she replied that,

this is sad, but the most that I've felt, and I know there's a place for everybody [in activist movements], but the most resistance I've felt has been from within the whole activist concept. It's very difficult. In the [school] Conference there was a lot of maneuvering after the students ran it with the teachers coming back in to run it. When we ran it, there really wasn't any trust that we could pull it off and it ended up being the biggest and best up to that point. That was a huge example of, you know, adult activists "eating their baby" ... disempowering young people, trying to take any power you do have away. Trying to co-opt that.

Her experience of tension within the field of activism reinforces the notion that there can be an inability or unwillingness on the part of older, experienced activists to make room for youth within their movements, even after these individuals have left high school and are legally considered adults themselves (Shaker, 2012). The reason for the lack of apprenticeship in these networks has not been well-documented, but there may be several factors that contribute to the unease that youth feel when entering into the "real world" of activism. Perhaps activists believe they are too busy to take on a mentorship role with youth or are themselves feeling the effects of burnout from engaging in the work they do (Gorski, 2015; Gorksi \& Chen, 2015), leaving young activists to find their own paths within the work. 
Another possible reason for a hostile reception to young activists in established groups is the idea that activists who have devoted their lives to particular causes may feel threatened by the arrival of younger activists and may fear becoming obsolete in their own movements (Rebick, 2013). Jealousy can result when the achievements of youth just emerging on the activist scene are recognized, an experience that Abigail encountered first-hand as a key youth organizer in the early stages of the Idle No More movement. Even though she was particularly adept at organizing events through social media on short notice and had important contacts within the movement itself, she often found herself relegated to menial tasks when working with older activists:

As a youth organizer, I was kind of, I was more like the helper, as opposed to someone on an equal playing field with these organizers that had years of experience ... they didn't even bother talking to me, they didn't bother sharing with me the layout of the day or the agenda, but the one thing they did make sure to ask me was to make sure that I picked up the garbage at the end of the rally.

Abigail pinpointed jealousy as a factor in her negative experiences working with adult activists, which may provide one clue as to the ongoing tokenization of capable, eager youth within these movements. Relegating youth to the status of "citizens-in-the-making" (Gordon, 2010, p. 205) rather than as equals in the fight for justice may be reflective of an adult perception of the need to socialize and prepare youth for the future.

The aforementioned limiting view of youth activists has them seen merely as assistants or workers rather than full-fledged activist partners, a conception of the young that essentially justifies assigning them insignificant or unappealing roles instead of engaging them in meaningful activism in the present (Taft \& Gordon, 2013). Having to consistently deal with situations of adultism (Bell, 2013; Taft, 2011; Taft \& Gordon, 2013) in which they are essentially forced to pay their dues, leaves some youth uninspired to join with and contribute to adult-led activist initiatives. Not being taken seriously in such organizations deprives those groups of insights and enthusiasm that youth can bring while also stripping the young people of important apprenticeship opportunities where they could enhance their skills and become tied to the larger activist community (Lund \& Nabavi, 2010). In so doing, youth can further understand the historical and current interconnections of the issues and those working to impact them (Garmulewicz \& Ireland, 2010; Ginwright \& Cammarota, 2007; Taft, 2011; Warner et al,, 2010; Wheeler \& Edlebeck, 2006).

\section{When Barriers Become Burdens}

Abigail's frustrations over having too little responsibility in the activist work she was passionate about directly contrasts with Chantal's experience of being buried beneath heavy responsibilities without an adequate knowledge or skill base to deal effectively with them. Chantal gave an extreme example of how her activist work came with larger burdens than she anticipated and with very little backup from any adults. She described her work in a youth-led group where she was a key organizer with little to no training in supporting others with their emotional or behaviourial issues. From dealing with suicidal youth to dealing with those with anger management problems, Chantal quickly learned of the importance of having adults to turn to for legal and emotional support when issues such as the following arose:

One time right before I left, there was a 13- or 14-year-old in the group who somehow ended up connecting with like a 20 -year-old. And there were allegations that they were 
having some sort of relationship and then all of a sudden [the adults in the sponsoring organization that donated space to the youth group] were like, "You're an accessory to statutory rape" and I was like, "What are you talking about? Like I'm just a kid!" ... And it was a liability issue, and I had to write out a statement and they're like, "The police are gonna call you at home" and I was like, "You gotta stand behind me, right?"

While Chantal very much appreciated the freedom in her youth-driven group, she recognized the need for a balance of both structured independence and support from adults or other organizations. The donations of a physical space for the group's meetings and minimal funding for supplies, while appreciated, were not enough in her case. Having escaped from any legal troubles from the situation described above, she was keenly aware of her own lack of knowledge in regard to complex legal and psychological issues. Youth like Chantal need reassurance that their adult mentors will support them when things go sideways in their activist worlds. Without this, youth could see their dreams dissolve as they wind up facing accusations or more serious consequences brought forward by adults who are less concerned with supporting their younger colleagues.

The support required by youth activists includes more than just legal counsel as would have been necessary in Chantal's case. Amelia talked about how she viewed all of the students she worked with as activists who were concerned about the world around them. She saw a sense of helplessness in youth who did not know where to begin in developing meaningful socially just projects. She had witnessed the hypocrisy these youth encountered when they received messages from both popular media and teachers and other adults that they would "be the change." At the same time, they were provided with no tools, support, or funding to fix the problems of the world they inherited (Lund \& Paul, 2014). Amelia's annoyance with the inadequacy of current schoolbased social justice training initiatives came through when she sarcastically added that kids consistently hear such encouragement as: "You can do this ... because you're creative!" with little further direction or assistance. Phrases designed to empower youth may instead cause them to freeze, unable to act due to the tremendous burden of dealing with problems that seem overwhelming and beyond the scope of their abilities.

Despite feeling that she was frequently given menial tasks due to her age, Abigail was also forced to deal with the problem of lacking the necessary emotional and social tools for engaging in activist work. Had she and her peers been given more support, they may not have felt as Abigail stated,

We were out there alone, so we felt like we were letting our heads hang in the wind too [laughs]. We felt like we were absorbing all this negative energy and jealousy, and anger, and it was really hard to not only experience that, as the counterpart, but to see how hurt and bullied we were. And for a bully to start understanding their actions, people have to call them out on it.

Knowledgeable, experienced, and concerned adults could have mentored Abigail through the process of calling out the bullying behaviour of these other activists, and importantly, they could have shielded her and her peers from the negative repercussions. Youth should not be saddled with the responsibility of making visible the negative, harmful actions that are sometimes performed by adults trying to maintain control over their activist movements. 


\section{Advice for Activist Educators}

It is likely unsurprising that the weighty responsibilities our participants mentioned, coupled with the conception of youth as not fully formed people, might result in feelings of despair on the part of these emerging activists. In spite of moments of frustration that participants shared, they noted that their feelings of disillusionment were countered or could be countered, either with the help of adult allies (Coe at al., 2015) or through their own evolving understandings of what it means to be an activist. Explicit and implicit mentions of the need for having safe spaces in which youth could learn about and engage in activist work, allowed them to feel more secure about what they were doing and their individual activist identities. The safe spaces that participants described in the interviews comprised both physical spaces within schools or other organizations, and the emotional spaces where they were free to be themselves and ask difficult questions about the issues with which they were most concerned. Building connections between students and individuals outside of the school community can expand those safe spaces beyond the school walls.

Designating actual physical, youth-led spaces in their schools, and then providing adult allies to support youth within those sometimes emotionally messy areas, could go a long way to helping young people become vital, skilled activists who feel competent in pushing for change. Some form of physical space was helpful for the youth we interviewed to feel as though they had agency to get involved and develop projects in their schools. Amelia and Josh were youth cofacilitators of one such space in an urban high school where the students were given the freedom to design the space and explore issues that piqued their interest. Their adult allies equipped Josh and Amelia with further knowledge and supplies-including financial assistance when necessary - so they could bring their projects to life. Jared, a student who actively used the space throughout his high school career, noted that these opportunities supplied him with the most memorable lessons from those four years.

While finding physical spaces that students can claim ownership over in schools is beneficial, it may not be absolutely necessary for the success of youth activist projects. Katie and Linda were both members of their high school social justice group and even though they did not have their own dedicated room for their work, aside from their teacher ally's classroom, they found a deep sense of belonging in being a part of this group. Linda explained,

I think really it was a group that was truly inclusive of diverse kids and back then there was a lot of different involvement. It gave us a space to kind of connect. There weren't a lot of groups at the time where I think alternative people would connect to.

Connecting to both peers with similar interests and an encouraging teacher in a similar safe space was foundational to Parmis' growth as an activist as well. She shared that one teacher, who "wasn't the nicest person you'd probably meet but she was very helpful," arranged a spot for Parmis in a youth camp where she expanded her leadership and organizing skills. Parmis believed this experience encouraged her to make the school clubs she founded inclusive of everyone, particularly international students who had been struggling with finding a "comfortable place to be" in the school.

Amelia noted that "safe spaces are messy places" and educators and mentors need to be prepared to deal with the discomfort that comes when young people feel comfortable enough to talk with their adult allies. Her experience with counseling youth whose personal lives were causing them to "fall apart" made her realize that the student-led space she co-facilitated was 
really a safe space for the youth. By providing them with a place to fall apart in, she was better able to "put supports and resources around them" to both help them through their current difficulties and teach them how to access resources in the future. Educators who establish respectful relationships with their students have a better chance of supporting youth through the messiness they will inevitably encounter in high school and throughout their activist careers.

Educators who are able to connect youth with activist communities outside of school can help students to expand their activist networks and potentially find other apprenticeship opportunities. Through their program, for example, Josh and Amelia utilized their own activist contacts in their city to bring individuals into their school to provide learning opportunities for their students about various relevant issues. They were also able to take students out into the city for different projects, such as planting fruit trees in the city's river valley as an accessible food source, learning from individuals doing restorative justice work, or partnering with local seniors to learn sustainability skills like woodworking, canning, or knitting. By finding community members they trust to partner with youth, these educators were trying to help students develop relationships and supports that they can still access after they leave high school.

\section{Conclusion}

Our research sought to identify some of the frustrations and limitations of activist work from the experiences of former youth leaders in social justice, and their insights can indeed inform those wishing to encourage greater youth participation in social justice projects. Teachers can be activist mentors to students while simultaneously providing access to other adults who can assist with the education of interested and eager youth. By looking at young activists as partners, or even as apprentices, as Garmulewicz and Ireland (2010) suggested, they can be encouraged into more meaningful roles within organizations, events, or movements with the support and mentorship of older, more experienced activists (London et al., 2003; Yohalem \& Martin, 2007). This may prevent youth from seeing more seasoned activists in the community as jealous or even vengeful as they reported in this research.

The young people with whom we collaborated for this research shared a number of sources of resistance to their social justice activism, including from fellow activists, school leaders, their own community members, and their adult mentors. It is essential for the adult mentors to create structures where young activists feel appreciated and capable of making a positive and significant impact. Giving youth access to personally and organizationally significant roles in movements, even while they are still in high school, could help them to see themselves as an integral part of the activist community and stop them from becoming adult activists who, "became the enemy they were fighting against." It could also link youth to other activist groups in their area because, as DePape (2012) said, "once you're plugged into one activist community you'll find yourself plugged into a whole activist network across Canada and the world" (p. 16).

The necessary collaboration that can occur in more supportive "intergenerational kinship networks" (Walia, 2012, p. 39) could go a long way to develop a more community-minded forms of activism from which everyone can benefit (O'Donoghue \& Strobel, 2007; Wheeler \& Edlebeck, 2006). We believe that the insights gained from the participants in this research hold much promise in informing future policy, planning, and curriculum in social justice education. By creating supportive and thoughtfully structured leadership opportunities for young people, 
educators and other adult mentors can provide the necessary contexts in which their junior activist colleagues can best learn and flourish. 


\section{References}

Bell, J. (2013). Understanding adultism: A key to developing positive youth-adult relationships. In M. Adams, W. J. Blumenfeld, C. R. Castañeda, H. W. Hackman, M. L. Peters, \& X. Zúñiga (Eds.), Readings for diversity and social justice ( $3^{\text {rd }}$ ed., pp. 542-549). New York, NY: Routledge.

Best, A. L. (2007). Introduction. In A. L. Best (Ed.), Representing youth: Methodological issues in critical youth studies (pp. 1-36). New York, NY: New York University Press.

Cabrera, N. L., Mesa, E. L., Romero, A. J., \& Rodriguez, R. C. (2013). "If there is no struggle, there is no progress": Transformative youth activism and the school of ethnic studies. The Urban Review, 45, 7-22.

Coe, A., Goicolea, I., Hurtig, A., \& Sebastian, M. (2015). Understanding how young people do activism: Youth strategies on sexual health in Ecuador and Peru. Youth \& Society, 47(1), $3-28$.

Conway, J., \& Morrison, D. (2007). A new political generation? Youth engagement in Canada and beyond. In L. Samuelson \& W. Antony (Eds.), Power and resistance: Critical thinking about Canadian social issues ( ${ }^{\text {th }}$ ed., pp. 243-264). Halifax, NS: Fernwood.

Creswell, J. W. (2007). Qualitative inquiry and research design: Choosing among five traditions (2nd ed.). Thousand Oaks, CA: Sage.

DePape, B. (2012). Power of youth: Youth and community-led activism in Canada. Our Schools, Our Selves, 21(3), 15-21.

Evans, R. E., \& Lund, D. E. (2013). Forging ethical adult-youth relationships within emancipatory activism. International Journal of Child, Youth and Family Studies, 3(1), 433-443. Retrieved from http://journals.uvic.ca/index.php/ijcyfs/issue/view/707

Flacks, M. (2007). "Label jars not people" How (not) to study youth civic engagement. In A. L. Best (Ed.), Representing youth: Methodological issues in critical youth studies (pp. 6083). New York, NY: New York University Press.

Forenza, B., \& Germak, A. J. (2015). What ignites and sustains activism: Exploring participatory competence. Journal of Progressive Human Services, 26(3), 229-245.

Garmulewicz, A., \& Ireland, L. (2010). The Canadian Youth Climate Change Conference (YC3) as a model for effective youth and adult engagement in promoting environmental and social justice. In W. Linds, L. Goulet, \& A. Sammel (Eds.), Emancipatory practices: Adult/youth engagement for social and environmental justice (pp. 145-164). Rotterdam, NL: Sense.

Ginwright, S., \& Cammarota, J. (2007). Youth activism in the urban community: Learning critical civic praxis within community organizations. International Journal of Qualitative Studies in Education, 20(6), 693-710.

Giroux, H. (2003). The abandoned generation: Democracy beyond the culture of fear. New York, NY: Palgrave Macmillan. 
Gordon, H. R. (2007). Allies within and without: How adolescent activists conceptualize ageism and navigate adult power in youth social movement. Journal of Contemporary Ethnography, 36(6), 631-668.

Gordon, H. R. (2008). Gendered paths to teenage political participation: Parental power, civic mobility, and youth activism. Gender \& Society, 22(1), 31-55.

Gordon, H. R. (2010). We fight to win: Inequality and the politics of youth activism. New Brunswick, NJ: Rutgers University Press.

Gordon, H. R., \& Taft, J. (2011). Rethinking youth political socialization: Teenage activists talk back. Youth \& Society, 43(4), 1499-1527.

Gorski, P. C. (2015). Relieving burnout and the "Martyr Syndrome"' among social justice education activists: The implications and effects of mindfulness. The Urban Review, 47, 696-716.

Gorski, P. C. (2019). Fighting racism, battling burnout: Causes of activist burnout in US racial justice activists. Ethnic and Racial Studies, 42(5), 667-687.

Gorski, P. C., \& Chen, C. (2015). "Frayed all over:” The causes and consequences of activist burnout among social justice education activists. Educational Studies, 51(5), 385-405.

Harris, A. (2004). Future girl: Young women in the twenty-first century. New York, NY: Routledge.

Kennelly, J. (2009a). Good citizen/bad activist: The cultural role of the state in youth activism. The Review of Education, Pedagogy, and Cultural Studies, 31, 127-149.

Kennelly J. (2009b). Youth cultures, activism and agency: Revisiting feminist debates. Gender and Education, 21, 259-272.

Kennelly, J. (2014). 'It's this pain in my heart that won't let me stop': Gendered affect, webs of relations, and young women's activism. Feminist Theory, 15(3), 241-260.

London, J. K., Zimmerman, K., \& Erbstein, N. (2003). Youth-led research and evaluation: Tools for youth, organizational, and community development. New Directions for Evaluation, $98,33-45$.

Lund, D. E. (2011). Examining shades of grey with students: Social justice education in action. Journal of Praxis in Multicultural Education, 6(1), 79-91. Retrieved from http://digitalscholarship.unlv.edu/cgi/viewcontent.cgi?article $=1055 \&$ context $=$ jpme

Lund, D. E., \& Grain, K. M. (2012). Learning from former student leaders in social justice activism. International Journal of Diversity in Education, 12(1), 13-25. Retrieved from http://ijde.cgpublisher.com/product/pub.244/prod.5

Lund, D. E., \& Nabavi, M. (2010). Renewing youth engagement in social justice activism. In B. J. Porfilio \& P. R. Carr (Eds.), Youth culture, education and resistance: Subverting the commercial ordering of life (pp. 91-107). Rotterdam, NL: Sense.

Lund, D., \& Paul, J. (2014). Off-loading self/other/world responsibilities: Confronting questionable ethics in youth engagement in critical pedagogy. In B. J. Porfilio \& $\mathrm{C}$. Mallot (Eds.), Critical pedagogy in the 21st century: A new generation of scholars (pp. 251-283). Charlotte, NC: Information Age. 
Lund, D. E., \& Van Beers, R. A. (2019). Learning from community agencies: Pre-service teachers' service-learning experiences with diverse youth. Journal of the World Federation of Associations of Teacher Education, 3(2a), 84-96.

Nabavi, M., \& Lund, D. E. (2012). The tensions and contradictions of living in a multicultural nation in an era of bounded identities. In J. Norris, R. D. Sawyer, \& D. E. Lund (Eds.), Duoethnography: Dialogic methods for social, health, and educational research (pp. 177-197). New York, NY: Routledge.

Norris, J., Sawyer, R. D., \& Lund, D. E. (Eds.). (2012). Duoethnography: Dialogic methods for social, health, and educational research. New York, NY: Routledge.

North, C. E. (2008). What is all this talk about "social justice"? Mapping the terrain of education's latest catchphrase. Teachers College Record, 110(6), 1182-1206.

O’Donoghue, J. L., \& Strobel, K. R. (2007). Directivity and freedom: Adult support of activism among urban youth. American Behavioral Scientist, 51(3), 465-485.

Rebick, J. (2013). On the streets. Our Schools, Our Selves, 22(3), 79-82.

Sawyer, R. D., \& Norris, J. (2013). Understanding qualitative research: Duoethnography. New York, NY: Oxford.

Sazama, J., \& Boston teens. (2013). Allies to young people: Tips and guidelines on how to assist young people to organize. In M. Adams, W. J. Blumenfeld, C. R. Castañeda, H. W. Hackman, M. L. Peters, \& X. Zúñiga (Eds.), Readings for diversity and social justice (3rd ed., pp. 582-584). New York, NY: Routledge.

Shaker, E. (2012). Preface. Our Schools, Our Selves, 21(13), 11-13.

Taft, J. (2011). Rebel girls: Youth activism and social change across the Americas. New York, NY: NYU Press.

Taft, J. K., \& Gordon, H. R. (2013). Youth activists, youth councils, and constrained democracy. Education, Citizenship and Social Justice, 8(1), 87-100.

Walia, H. (2012). Young, brown and proud: Personal purpose and political activism. Our Schools, Our Selves, 21(3), 31-40.

Warner, A., Langlois, M., \& Dumond, C. (2010). Voices from youth action teams. In W. Linds, L. Goulet, \& A. Sammel (Eds.), Emancipatory practices: Adult/youth engagement for social and environmental justice (pp. 95-108). Rotterdam, NL: Sense.

Wheeler, W., \& Edlebeck, C. (2006). Leading, learning, and unleashing potential: Youth leadership and civic engagement. New Directions for Youth Development, 109, 89-97.

Yohalem, N., \& Martin, S. (2007). Building the evidence base for youth engagement: Reflections on youth and democracy. Journal of Community Psychology, 35(6), 807-810.

Endnote:

1. All of the participant names are pseudonyms. 